\title{
TUMBUH KEMBANG ANAK BROKEN HOME
}

\author{
Fitriyani Lie $^{1}$, Pupung Puspa Ardini ${ }^{2}$, Setiyo Utoyo ${ }^{3}$, Yenti Juniarti ${ }^{4}$ \\ Fakultas Ilmu Pendidikan, Universitas Negeri Gorontalo \\ Email: fitriyanilie64@gmail.com
}

\begin{abstract}
Abstrak
Penelitian ini berlatarbelakang anak yang mengalami broken home yang bertujuan untuk mengetahui pertumbuhan dan perkembangan anak usia dini (4 tahun) sampai ia remaja berusia 18 tahun yang menjadi korban broken home Di Sulawesi Tengah, Kabupaten Banggai, Kecamatan Masama, Desa Ranga-Ranfa. Jenis penelitian ini adalah kualitatif dengan pendekatan studi kasus terhadap perkembangan dan pertumbuhan anak yang menjadi korban broken home. Subjek penelitian adalah seorang remaja perempuan berusia 18 tahun merupakan anak korban broken home. Tehnik pengumpulan data dengan observasi, wawancara dan kuesioner. Hasil penelitian menunjukan bahwa terjadinya broken home mengakibatkan tidak terpenuhinya kebutuhan anak, terutama perhatian dan kasih sayang yang seharusnya di dapatkan dari kedua orang tunya, akan tetapi AR tetap memiliki rasa aman, mendapatkan perlindungan, suka berempati dan berbagi dengan orang lain. AR adalah salah satu anak yang menjadi korban broken home mengalami pertumbuhan dan perkembangan sesuai dengan anak seusianya. Sehingga AR pun tidak memerlukan penanganan khusus.
\end{abstract}

Kata kunci: Anak, Broken Home

\begin{abstract}
This research has the background of a child who has broken home in order to determine the growth and development of early childhood (4 years) until he is an 18 year old teenager who is a victim of broken home in Central Sulawesi, Banggai District, Masama District, Ranga-Ranfa Village. This type of research is a qualitative case study approach to the development and growth of children who are victims of broken homes. The subject of the study was an 18-yearold girl who was a victim of a broken home. Data collection techniques with observation, interviews and questionnaires. The results showed that the occurrence of broken home resulted in not meeting the needs of children, especially the attention and affection that should be received from both parents, but the AR still has a sense of security, get protection, like to empathize and share with others. AR is one of the children who are victims of broken home experiencing growth and development in accordance with their age. So that AR does not require special handling.
\end{abstract}

Keywords: Broken Home, Child

(C) 2019 Fitriyani Lie ${ }^{1}$, Pupung Puspa Ardini ${ }^{2}$, Setiyo Utoyo ${ }^{3}$, Yenti Juniarti ${ }^{4}$ Under the license CC BY-SA 4.0

http://jurnal.upmk.ac.id/index.php/pelitapaud 


\section{PENDAHULUAN}

Pendidikan anak usia dini adalah suatu upaya pembinaan yang ditujukan pada anak sejak lahir sampai usia enam tahun yang dilakukan melalui pemberian rangsangan pendidikan lebih lanjut (Depdiknas, 2011). Anak usia dini merupakan salah satu modal dasar dan utama yang sangat berharga untuk menghasilkan sumber daya manusia yang berkualitas.

Menurut Moeliono remaja adalah orang yang masuk dalam kelompok usia 10-19 tahun, kelompok ini juga masih dapat disebut anak (0-18 tahun) sesuai dengan definisi UndangUndang Perlindungan Anak Indonesia. Selanjutnya dikatakan bahwa anak remaja adalah masa peralihan dari masa kanak-kanak menuju masa dewasa (10-24 tahun)

Dalam kehidupan manusia terdapat dua proses kejiwaan yang terjadi, yaitu pertumbuhan dan perkembangan yang biasanya disingkat dengan tumbuh kembang. Pada umumnya istilah pertumbuhan dan perkembangan digunakan secara bergantian. Padahal kedua proses ini berlangsung secara interdependensi, artinya saling bergantung antara satu sama lain. Kedua proses itu tidak dapat dipisahkan, tetapi dapat dibedakan untuk memperjelas penggunaanya antara tumbuh dan berkembang.

Pertumbuhan berkaitan dengan perubahan fisik secara kuantitatif yang menyangkut peningkatan ukuran dan struktur biologis. Sendangkan Proses perkembangan bersifat kualitatif. menurut Warner (1957) berlangsung dari keadaan global dan kurang berdiferensiasi sampai pada keadaan diferensiasi,artikulasi dan integrasi meningkat secara bertahap. Proses diferensiasi bersifat totalitas pada diri anak bahwa bagian-bagian penghayatan totalitas itu lambat laun semakin nyata dan bertambah jelas dalam kerangka keseluruhan. Selama perkembangannya, individu akan tetap menerima dan memperoleh hal-hal baru, terutama yang berhubungan dengan kehidupan psikisnya. Sebab pada diri manusia terdapat naluri dan kebutuhan untuk memperoleh dan mengetahui sesuatu. Jika kebutuhan ini tidak terpenuhi akan timbul rasa kecewa dan penderitaan secara psikis(kejiwaan). Kebutuhan psikis anak merupakan kegiatan yang selalu meningkat seperti yang terlihat pada sikap atau tingkah laku anak begitupun 
dengan remaja yang sering terlihat sifat bosan terhadap sesuatu dan ingin selalu melakukan dan memperoleh hal baru yang ada di lingkungannya.

Keluarga yang disebut broken home dapat mempengaruhi tumbuh kembang anak dalam keluarga. Perkembangan dalam keluarga terganggu dengan adanya masalah keluarga. Keluarga merupakan tempat yang penting untuk perkembangan anak secara fisik, emosi, spritual, dan sosial. Menurut hasil penelitian (Saikia, 2017) mengenai broken family: its causes and effects on the development of children atau penyebab dan dampak dari broken home pada perkembangan anak menjelaskan bahwa salah satu penyebab keluarga broken home adalah perceraian orang tua. Padahal keluarga itu sendiri memiliki fungsi yang sangat penting untuk keberlangsungan masyarakat dari generasi ke generasi (Lestari, 2012).

Perceraian secara langsung dan tidak langsung dapat memberikan dampak spikologis yang buruk bagi anak. Dampak langsung yang dirasakan adalah perasaan kehilangan salah satu sosok orang tua yang biasanya mereka jumpai setiap hari. Menurut Loughlin (2016) menunjukan bahwa anak-anak atau remaja yang menghadapi perceraian orang tuanya biasanya mengalami gejala gangguan kesehatan mental jangka pendek, yaitu stres, cemas, dan depresi. Seperti yang dilansir menurut healthmeu.com (2015) terdapat delapan dampak bagi anak sebagai korban perceraian dari orang tuanya. Delapan dampak tersebut adalah penurunan akademik, kecenderungan untuk terpengaruh hal buruk, kualitas kehidupan yang rendah, mengalami pelecehan, obesitas dan gangguan makan, tekanan psikologis, apatis dalam berhubungan, dan melakukan seks bebas.

Peran orang tua dan pendidik pada dasarnya mengarahkan anak-anak sebagai generasi unggul, karena potensi anak tidak akan tumbuh dan berkembang dengan sendirinya tampa bantuan orang tua dan orang yang ada disekitarnya. Orang tua memegang peranan penting dalam menciptakan lingkungan yang aman dan nyaman untuk anak guna memotivasi anak agar dapat lebih siap dalam menghadapi berbagai tantangan di masa depan nanti.

Menurut Soedarjito (2017) keluarga merupakan pusat pendidikan pertama yang dikenal anak, keluarga 
mempunyai peran mensosialisasikan adat istiadat, kebiasaan, peraturan, nilai-nilai, atau tata cara kehidupan. Keluarga merupakan satu kesatuan lingkungan sosial pertama bagi anak dan tempat mendapatkan anak perlindungan, kasih sayang serta rasa aman dan kebutuhan yang lainnya. Jika dalam keluarga terjadi kesenjangan hubungan itu perlu diimbangi dengan kualitas dan intensitas hubungan sehingga ketidakberadaan kedua orang tuanya baik ayah maupun ibu tetap dirasakan kehadirannya dan dihayati secara psikologis oleh anak.

Broken home memiliki beberapa arti atau makna tergantung dari kacamata kita melihatnya dan dari arti mana kita memahaminya. Dari beberapa wawancara yang saya lakukan langsung dari anak yang mengalami broken home mengutamakan bahwa kondisi keluarganya atau orang tuanya yang tidak harmonis dan tidak pada umumnya keluarga yang aman, rukun, damai, dan harmonis. Biasanya keluarganya sering terjadi pertengkaran, perdebatan dan perselisihan yang ditimbulkan oleh hal kecil atau sepeleh. perceraian adalah penyebab stres kedua paling tinggi, setelah kematian pasangan. Seringkali perceraian diartikan sebagai kegagalan yang dialami suatu keluarga (Abib 2009).

Kondisi ini yang mengakibatkan seorang anak menjadi murung dan sedih yang berkepanjangan serta malu terhadap kondisi keluarga yang hancur dan tidak harmonis lagi. Bahkan ada beberapa anak dari broken home yang merasa putus asa dengan hidupnya sehingga ia melakukan halhal negatif seperti mulai merokok, narkoba dan minuman keras dan halhal negatif yang didapatkan dari lingkungan pergaulannya. Karena disaat itulah mereka merasa tenang dan merasa bebas, tanpa ada dampingan/bimbingan orang tua mereka, yang ada dipikiran mereka hanyalah mencari kesenangan sesaat dan dapat melupakan serta meluapkan masalah mereka saat itu. Mereka tidak memperdulikan orang lain lagi disekeliling mereka, bahkan ada juga anak broken home yang tidak pernah memikirkan masa depan, yang mereka pikirkan lepas dari keluarga mereka. tetapi ada pula anak yang menjadikan broken home orang tunya itu sebuah motivasi atau pembelajaran bahwa dirinya bisa sukses dan mebuktikan 
pada orang-orang saya mampu walau tampa kasih sayang orang tua yang lengkap.

Berdasarkan informasi yang di dapatkan di sebuah kos-kosan di JL. Pangeran Hidayat 2 Kota Gorontalo pada hari kamis 12 Desember 2019 terdapat remaja yang merupakan korban broken home. Peneliti pun tertarik untuk mengkaji lebih dalam tentang pertumbuhan dan perkembangan anak yang menjadi broken home tersebut .

Dari latar belakang diatas maka muncul sebuah pertanyaan "bagaimana tumbuh kembang anak yang mengalami masalah broken home".

\section{METODE PENELITIAN}

Penelitian ini menggunakan penelitian kualitatif dengan pendektan studi kasus . Menurut meleong (2005), penelitian kualitatif adalah penelitian yang bermaksud untuk memahami fenomena tentang apa yang dialami oleh subjek penelitian misalnya, perilaku, persepsi, motivasi, tindakan, dll secara holistic dan dengan cara deskripsi dalam bentuk kata-kata dan bahasa, pada suatu konteks khusus yang alamiah dan dengan memanfaatkan berbagai metode alamiah. Dan pendekatan studi kasus menurut Mulyana (2008) adalah uraian dan penjelasan komprehensif mengenai berbagai aspek seorang individu, suatu kelompok, suatu organisasi (komunitas), suatu program, atau suatu situasi sosial.

Lokasi penelitian di tempat tinggal anak tersebut JL.Pangeran Hidayat 2 Kota Gorontalo. Waktu penelitian pada kamis, 12 Desember 2019.

Subjek penelitiannya adalah seorang remaja perempuan korban broken home yang berusia 18 tahun. Ia menjadi korban broken home sejak berusia 4 tahun.

Peneliti mendapatkan informasi dari teman kuliahnya bahwa ia memiliki teman yang mengalami masalah broken home. Sehingga peneliti manjadikannya subjek penelitian karena kasusnya sesuai dengan apa yang akan di teliti yaitu pertumbuhan dan perkembangan anak broken home.

\section{Peneliti} melakukan penelitiannya dengan mengunjugi langsung tempat tinggal remaja yang menjadi korban broken home. Remaja ini tinggal di sebuah kos-kosan yang berada di jln Pangeran Hidayat 2 Kota 
Gorontalo. Dengan menanyakannya lagsung kepada korban broken home tersebut saya mendapatkan beberapa data perjalanan hidup sejak ia berusia 4 tahun dan semenjak itupulah keluarganya hancur.

Metode pengumpulan data dalam penelitian ini adalah wawancara, pengamatan observasi dan kuesioner. Dalam metode wawancara ini merupakan salah satu metode yang dapat dipercaya untuk mendapatkan data tentang individu yang dilakukan dengan pemberian pertanyaanpertanyaan yang relevan secara tatap muka, peneliti melakukan wawancara kepada subjek atau anak yang menjadi korban broken home tersebut. Metode observasi diartikan sebagai pengamatan dan pencatatan secara sistematik gejala yang tampak pada obyek penelitian. Kuesioner yang dimaksud dalam penelitian ini adalah sejumlah pertanyaan tertulis yang digunakan untuk memperoleh dari informasi reponden dalam arti laporan tentang pribadinya atau hal-hal yang ia ketahui. Teknik analisis data yang digunakan dalam penelitian ini adalah reduksi data, penyajian data, dan penarikan kesimpulan.

\section{HASIL PENELITIAN DAN PEMBAHASAN}

Berdasarkan hasil penelitian ini diperoleh bahwa anak remaja yang merupakan salah satu mahasiswa di universitas yang ada digorontalo yaitu di UNG (Unuversitas Negeri Gorontalo). Anak remaja ini bernama AR berusia 18 tahun yang merupakan anak korban broken home. Dari observasi dan wawancara yang saya lakukan saya mendapatkan informasi bahwa sejak lahir AR di rawat oleh nenek kakek dan tantenya. Nenek AR mengalami lumpuh dan tantenya berhenti sekolah dikarenakan waktunya di luangkan untuk merawat AR sejak lahir. Kebutuhan AR itu di tanggung oleh nenek dan kakeknya meskipun sesekali orang tuanya yang menanggung dengan mengirimkan uang untuk kebutuhan si AR.

Tetapi setelah bercerai kebutuhan si AR di tanggung sepenuhnya oleh kakek, nenek dan tantenya. Penyebab ayah dan ibunya bercerai itu belum diketahui pasti hanya saja si AR mendengar banyak isu yang beredar penyebabnya karena adanya orang ketiga dan mungkin dikarenakan sifat ibunya yang masih berjiwa muda (ibunya menikah diusia 
13 tahun) dan pernikahan ayah dan ibunya hanya karena di jodohkan. Setelah orang tuanya bercerai beberapa bulan kemudian si AR mendengar ayahnya menikah dan semenjak itupulah si AR hilang komunikasi dengan ayahnya itu karena ibu tirinya yang melarang ayahnya untuk berkomunikas ataupun bertemu dengan AR . Dua tahun kemudian ibu AR pun menikah dan semenjak itu semakin hilang kasih sayang yang diberikan ibunya, ibunya pun pergi jauh dan kembali ketika si AR sudah menginjak bangku sekolah kelas 1 SMA.

Akibat dari broken home yang dialami si AR sejak ia berusia 4 tahun tingkah lakunya berubah. si AR sempat merasa tidak ada gunanya hidup tanpa orang tua yang lengkap tanpa kasih sayang orang tua. AR juga merasa iri sama teman-temannya yang orang tuanya masih lengkap. Sejak orang tuanya broken home AR menjadi orang yang tertutup dan lebih memendam perasaan hingga lebih tergesa-gesa dalam mengambil tindakan. Ia menjadi seorang yang pembenci bahkan menjadi orang yang sulit percaya dan sulit memaafkan orang yang berbuat salah padanya.
Si AR merasa hidupnya sangat sial ketika mendengar ayahnya meninggal karena semenjak orang tuanya bercerai ia tidak pernah mendengar kabar dari ayahnya dan setelah mendapat kabar, ayahnya sudah meninggal (selama 12 tahun penantian untuk bertemu sang ayah akhirnya tidak kunjung bertemu dan tidak akan pernah bertemu selama-lamanya) AR pun semakin rapuh dan hancur seakanakan AR tidak sanggup lagi menjalani hari-harinya akan tetapi berkat dukungan, motivasi serta kasih sayang yang diberikan keluarga dan lingkungannya serta dengan bertambah usianya ia mulai menyadari sikapnya yang mulai berubah dan akhirnya AR memutuskan untuk bangkit kembali menjalani hari-hari seperti anak lain pada umumnya. AR tetap melanjutkan sekolah seperti biasanya, tetap semangat meraih prestasi bahkan broken home yang dialami orang tuanya menjadikannya ambisi dan motivasi bahwa AR harus sukses dan membuktikan pada semua orang bahwa dirinya mampu walau tanpa kasih sayang orang tua yang lengkap. Dan anak korban broken home ini mempunyai prinsip bahwa hidup tidak untuk disesali atau dikeluhkan, tapi 
hidup untuk dijalani dan dihadapi dengan ikhlas. Banyaknya masalah dan beban bukan alasan untuk menyerah. Itulah yang dikatakan oleh seorang anak broken home yang dialaminya sejak ia berusia 4 tahun.

Dari hasil penelitian yang diperoleh bahwa terjadinya broken home mengakibatkan tidak terpenuhinya kebutuhan anak, terutama perhatian dan kasih sayang yang seharusnya di dapatkan dari kedua orang tuanya, akan tetapi anak tetap memiliki rasa aman, mendapatkan perlindungan, suka berempati dan berbagi dengan orang lain.

Anak broken home mengalami pertumbuhan dan perkembangan sesuai dengan anak seusianya. Lingkungan rumah dan lingkungan sekitarnya di tanah rantau pun memberikan hal positif, peduli serta memberikan perhatian yang baik sehingga dapat membantu pertumbuhan dan perkembangannya sesuai dengan tingkat perkembangan anak pada umumnya. Pada dasarnya anak broken home mau untuk di ajak berbicara dari hati-kehati, mereka mau untuk diajak kerja sama merubah keadaan mereka yang terpuruk untuk kehal-hal yang lebih baik. Dengan adanya keluarga dan lingkungan sekitar yang baik yang selalu memberikan dukungan dan kasih sayang anak broken home merasakan ada yang memperhatikan dan memeprdulikan mereka.

Sehingga penelitian ini pun memperkuat penelitian sebelumnya yang mengatakan bahwa anak broken home selain memiliki dampak negatif juga terdapat dampak positif (Wati, 2010), dan untuk dampak negatifnya di perkuat oleh hasil penelitian menegenai kondisi psikologis anak dalam keluarga yang bercerai menjelaskan bahwa dampak yang dirasakan oleh anak korban perceraian orang tuanya antara lain: merasa tidak aman, adanya rasa penolakan dari keluarga, marah sedih kesepian dan perasaan menyalahkan diri sendiri sehingga penelitian sebelumnya ini menyatakan bahwa korban broken home memiliki sikap negatif (Sarbini dan Kusuma, 2014). Dan untuk dampak positifnya seperti apa yang telah dijelasakan diatas tidak semua anak broken home masa depannya hancur. Dan perkembangan serta pertumbuhan anak yang mengalami masalah broken home sesuai dengan tingkat pencapaian perkembangan hal ini mendukung penelitian terdahulu bahwa prestasi 
belajar anak broken home cukup baik (Pramdian, 2010) dan perkembangan sosial emosonal anak korban broken home sesuai dengan tingkat pencapaian perkembangan anak (Nugraheni, 2014).

Menjadi anak dari keluarga broken home tidak selamanya buruk karena tidak menutup kemungkinan latarbelakang keluarga broken home dapat dipandang dari sisi yang lebih positif. Ada hikma yang dapat diambil sebagai motivasi bagi korban broken home untuk menjadi individu yang lebih positif. Sikap mandiri yang tercipta karena tuntutan beradaptasi dengan keadaan hidup yang harus dijalani tanpa perhatian dari orang tua. Sikap kedewasaan biasanya muncul pada diri korban broken home karena terbiasa menghadapi masalah sendiri dan bertanggung jawab atas dirinya sendiri (Wulandari dan Fauziah, 2019).

\section{SIMPULAN}

Berdasarkan hasil penelitian dapat disimpulkan bahwa Akibat dari broken home yang dialami si AR sejak ia berusia 4 tahun tingkah lakunya berubah. si AR sempat merasa tidak ada gunanya hidup tanpa orang tua yang lengkap tanpa kasih sayang orang tua. AR juga merasa iri sama temantemannya yang orang tuanya masih lengkap. Sejak orang tuanya broken home AR menjadi orang yang tertutup dan lebih memendam perasaan hingga lebih tergesa-gesa dalam mengambil tindakan. Ia menjadi seorang yang pembenci bahkan menjadi orang yang sulit percaya dan sulit memaafkan orang yang berbuat salah padanya.

Si AR merasa hidupnya sangat sial ketika mendengar ayahnya meninggal karena semenjak orang tuanya bercerai ia tidak pernah mendengar kabar dari ayahnya dan setelah mendapat kabar, ayahnya sudah meninggal (selama 12 tahun penantian untuk bertemu sang ayah akhirnya tidak kunjung bertemu dan tidak akan pernah bertemu selama-lamanya) AR pun semakin rapuh dan hancur seakanakan AR tidak sanggup lagi menjalani hari-harinya akan tetapi berkat dukungan, motivasi serta kasih sayang yang diberikan keluarga dan lingkungannya serta dengan bertambah usianya ia mulai menyadari sikapnya yang mulai berubah dan akhirnya AR memutuskan untuk bangkit kembali menjalani hari-hari seperti anak lain pada umumnya. AR tetap melanjutkan sekolah seperti biasanya, tetap 
semangat meraih prestasi bahkan broken home yang dialami orang tuanya menjadikannya ambisi dan motivasi bahwa AR harus sukses dan membuktikan pada semua orang bahwa dirinya mampu walau tanpa kasih sayang orang tua yang lengkap. Dan anak korban broken home ini mempunyai prinsip bahwa hidup tidak untuk disesali atau dikeluhkan, tapi hidup untuk dijalani dan dihadapi dengan ikhlas. Banyaknya masalah dan beban bukan alasan untuk menyerah. Itulah yang dikatakan oleh seorang anak broken home yang dialaminya sejak ia berusia 4 tahun.

$$
\text { terjadinya broken home }
$$

mengakibatkan tidak terpenuhinya kebutuhan anak, terutama perhatian dan kasih sayang yang seharusnya di dapatkan dari kedua orang tunya, akan tetapi anak remaja yang berusia 18 tahun yang merupakan salah satu mahasiswa Universitas Negeri Gorontalo menjadi korban broken home sejak ia berusia 4 tahun ini tetap memiliki rasa aman, mendapatkan perlindungan, suka berempati dan berbagi dengan orang lain sehingga pertumbuhan dan perkembangan sudah berkembang sesuai dengan tahapan perkembangannya sehungga tidak memerlukan penanganan khusus.

\section{DAFTAR PUSTAKA}

Fatih Al Angga (2019). Teknik Pengumpulan Data. Diakses 10 Oktober $2019 \quad$ Dari https://rumus.co.id/teknikpengumpulan-data/

Hasnida, (2015). Analisis Kebutuhan Anak Usia Dini. Jakarta Timur: PT.Luxima Metro Media.

Nugraheni Novitasari Putri. (2014). Perkembangan Psikologi Anak Usia Dini Korban Broken Home Di POS PAUD Ananda Bowan Delanggu Kabupaten Klaten Tahun Pelajaran 2013-1014. Surakarta: Universitas Muhammadiyah Surakarta.

Putri Azmila (2018). Dampak Psikologi Anak Korban "Broken Home". Diakses Tanggal 20 Oktober 2018 Dari https://www.kompasiana.com/azmi la99189/5bca9f1b6ddcae59e53381 44/dampak-psikologi-anak-korbanbroken-home?page=1

Suhada Idad, (2016). Psikologi perkembangan anak usia dini (Raudhatul Athfal). Bandung: PT Remaja Rosdakarya Offset.

Wulandari Desi dan Fauziah Nailul (2019). Pengalaman remaja korban broken home (studi kualitatif Fenomenologis). Jurnal Empati, 8 (1),

2-3. 